SYMBOLAE PHILOLOGORUM POSNANIENSIUM GRAECAE ET LATINAE XXIV/1 • 2014
pp. 281-287. ISBN 978-83-7654-279-9. ISSN 0302-7384

DOI: 10.14746/SPPGL.2014.XXIV.1.15

\title{
MARCIN LOCH
}

Instytut Filologii Klasycznej Uniwersytetu im. Adama Mickiewicza

ul. Fredry 10, 61-701 Poznań

Polska - Poland

\section{KILKA UWAG NA TEMAT POLSKIEJ EDYCJI SEKSUALIZMÓW ŁACIŃSKICH JAMESA N. ADAMSA ${ }^{1}$}

\begin{abstract}
Loch Marcin, Kilka uwag na temat polskiej edycji Seksualizmów łacińskich Jamesa N. Adamsa (A few observations on the Polish edition of The Latin Sexual Vocabulary by James N. Adams).

Last year, Homini Publishing House published a Polish edition of The Latin Sexual Vocabulary by J.N. Adams. The translation was made by J. Janik. In comparison with the original English version, the Polish edition has been enriched with translations of its Latin quotations. In this paper, I will carry out a critical review of the Polish edition of the book.
\end{abstract}

Keywords: the Latin sexual vocabulary, Latin obscenities, Roman sexuality, Martial, Pompeian inscriptions.

Praca Jamesa N. Adamsa zatytułowana The Latin Sexual Vocabulary (Princeton 1982) została przyjęta przez środowisko naukowe dość krytycznie. Autorzy recenzji byli jednak zgodni co do jednego: książka stanowi olbrzymi zbiór i przegląd łacińskiej leksyki erotycznej, który można polecić każdemu, kto chciałby ogólnie zapoznać się z tym, jak funkcjonuje w łacinie słownictwo dotyczące intymnych sfer życia człowieka. Zainteresowanym szczegółową krytyką angielskiego oryginału polecić można bardzo skrupulatną recenzję A. Richlin², oraz inne recenzje o charakterze bardziej ogólnym³ ${ }^{3}$ W niniejszej publikacji nie zamierzam powielać opinii autorów wyżej wymienionych recenzji, ale czasem odwołując się do nich, podzielić się pewnymi przemyśleniami i uwagami, które nasunęły mi się w trakcie lektury polskiej edycji tego opracowania, a które doty-

\footnotetext{
${ }^{1}$ Niniejszy tekst jest omówieniem książki: J.N. Adams, Seksualizmy łacińskie, przekł. J. Janik, Wydawnictwo Homini, Kraków 2013, ss. 367.

${ }^{2}$ A. Richlin, AJPh 105, 1984, s. 491-494.

${ }^{3}$ A.D. Booth, „Phoenix” 37, 1983, s. 362-364; E. Regal, „The Classical World” 77, 1983, s. 132; R. Verdière, „Latomus” 44, 1985, s. 225-226; D.R. Shackleton Bailey, „Classical Philology” 80, 1985, s. 83-85; M.B. Skinner, „The Classical Word” 77, 1983, s. 56.
} 
czą częściowo samej płaszczyzny merytorycznej pracy, jak i przede wszystkim spolszczenia cytatów łacińskich w niej zawartych.

Długo zapowiadana i z niecierpliwością oczekiwana polska edycja książki Adamsa pt. Seksualizmy łacińskie w tłumaczeniu Joanny Janik ukazała się w ubiegłym roku nakładem Wydawnictwa Homini. Wydarzenie o tyle bardzo wyczekiwane, że tłumaczka postawiła sobie trudne zadanie wzbogacenia polskiej edycji o przekład wszystkich cytatów łacińskich tam obecnych, za co należy wyrazić szczególne uznanie. Przekład niezliczonej liczby cytatów wyrwanych z kontekstu wymaga bez wątpienia olbrzymiej pracy, zwłaszcza gdy weźmie się pod uwagę trudności, jakie należy pokonać w oddawaniu w językach współczesnych łacińskiej terminologii erotycznej. Trudności te wynikają głównie ze zmian kulturowych dotyczących postrzegania ludzkiej seksualności, jakie dokonały się na przestrzeni dziejów, głównie pod wpływem myśli chrześcijańskiej. $\mathrm{Z}$ powodu tych różnic niełatwo szukać $\mathrm{w}$ językach nowożytnych adekwatnych odpowiedników poszczególnych terminów. Można odnieść wrażenie, że bez odważnych neologizmów - które jednak mogłyby zostać niewłaściwie zrozumiane - zadanie takie jest wręcz niemożliwe do wykonania. Tłumaczka postanowiła rozwiązać ten problem wykorzystując słownictwo poświadczone w języku polskim, co jest jak najbardziej zrozumiałe, choć nie zawsze dobrze się sprawdza, np. w przekładzie często dla oddania łacińskiego inguina, ilia czy pudenda pojawia się archaiczne (pochodzące z pierwszej połowy XVII wieku) słowo „słabizna” (s. 187: „słabizny pokosztujesz”; s. 77: „,zmaltretowana słabizna biednego Wiktora”; s. 223 „ogromną słabiznę”), które obecnie - jak się zdaje - nie jest powszechnie zrozumiałe.

Praca Adamsa zawiera pewne mankamenty, które zostały ogólnie przedstawione przez autorów wymienionych już recenzji angielskiego oryginału. Mankamenty te są obecne również w polskiej edycji pracy, ponieważ wydawcy wyszli z założenia, że zadaniem tłumacza nie jest polemika z autorem, ale oddanie w języku polskim treści oryginału - nawet tych, z którymi się nie zgadzają ${ }^{4}$. Z tego powodu zdarzają się miejsca, w których czytelnik zauważa niespójność między polskim przekładem danego cytatu a jego interpretacją: tj. do źle zinterpretowanego przez Adamsa cytatu dołączony jest dobry polski przekład, np. s. 171: ego tibi istam hodie, sceleste, comprimam linguam - hau potes: bene pudiceque servatur - ,już ja ci dziś, łajdaku, jęzor przykrócę - nie możesz: jest dobrze i przyzwoicie strzeżony”. Sensem tego dialogu jest: „przestań, bo ja sprawię, że się udławisz tym językiem - spróbuj, to ci go [scil. członek] zębami odgryzę”. Adams natomiast rozumie czasownik servatur jako „zachowuje się” zamiast servatur scil. dentibus, o czym świadczy komentarz: ,[...] ten bierze pogróżkę jako groźbę zamknięcia mu ust przez irrumatio i odpowiada, że to się nie uda, ponieważ nie posługuje się w ten sposób językiem. W potocznej, dość

\footnotetext{
${ }^{4}$ Być może, warto byłoby skomentować dyskusyjne partie tekstu odpowiednim przypisem.
} 
wulgarnej, łacinie dialog ten mógłby brzmieć następująco: irrumabo te - non fello". Ewidentnie gwałt polega na tym, by zrobić komuś coś, czego ten ktoś nie lubi, dlatego dialog między oprawcą a ofiarą te irrumabo - non fello, który przyrównać można do dialogu typu: „zgwałcę cię - nie, dziękuję”, nie ma sensu. Jest to jeden z przykładów, w których Adams zdaje się nie rozumieć jednej z najbardziej podstawowych kwestii dotyczących rzymskiej seksualności: opozycji między byciem stroną aktywną a stroną pasywną ( $\mathrm{tj}$. dominującą i zdominowaną) w trakcie stosunku ${ }^{5}$. Na przykład czasownik irrumare w łacinie prawie zawsze implikuje gwałt (podczas gdy w opracowaniu Adamsa na s. 173 znaleźć można następujące stwierdzenie: ,,irrumo mogło być jednak zupełnie pozbawione emotywnego nacechowania" ${ }^{6}$ ), natomiast fellare jest zawsze nacechowane woluntatywnie. Zależność tego, od kogo wychodzi inicjatywa i kto z czynności odbiera przyjemność, jest ściśle powiązana z dominacją i uległością, które są fundamentalnym elementem rzymskiej koncepcji ludzkiej seksualności ${ }^{7}$. O ile w przypadku fellatio i irrumatio łatwo orzec, który z partnerów jest stroną aktywną, o tyle trudniej jednoznacznie określić to w przypadku cunnilinctio. Adams stwierdza ${ }^{8}$, że w takim stosunku mężczyzna jest stroną aktywną, podczas gdy wiele przykładów z literatury łacińskiej wyraźnie wskazuje, że tak nie jest ${ }^{9}$.

Skoro już mowa o stosunku oralnym: przekład cytatu ze s. 167: Mart. XI 40.3 Glycerae dolere dentes „Glykerę o ból zęby przyprawiają” w zestawieniu z dalszym komentarzem Adamsa: ,passus sugeruje, że Glykera była fututa ore - obsłużona ustami”, może sugerować, że chodzi o cunnilinctio, podczas gdy tematem epigramu jest irrumatio. Żona nie jest tutaj odbiorcą przyjemności, ale jej dawcą - stąd przekład „obsłużona ustami” jest nieprawidłowy. Żart w tym miejscu polega na tym, że stary mężulek przechwala się piękną żoną i swoją potencją - gdy skarży się, że od miesiąca nie miał z nią stosunku (non esse fututam), niezamierzenie ujawnia, iż nie penetruje jej waginy, ale usta (irrumat). $\mathrm{W}$ ten sposób zdradza, że ma jednak problemy z potencją, a długie stosunki oralne z żoną powodują u niej już ból zębów (cf. Mart. IV 50 \& XI 46). Adams często niezręcznie posługuje się terminem futuere, stosując go jak angielskie to fuck (cf. s. 166 culus qui futuitur; futuo = pedico, ibidem), co również znajduje krytykę w powyższych recenzjach.

$\mathrm{Z}$ kolejnym przykładem niezręcznej interpretacji mamy do czynienia na s. 166: (Mart. XI 22) inguina saltem / parce fututrici sollicitare manu „,niech twoja lubieżna dłoń oszczędzi przynajmniej jego słabiznę". Sensem tego zdania jest raczej: „przestań masturbować go swoją ręką pełną żądzy, która próbuje

\footnotetext{
${ }^{5}$ Szerzej na ten temat: H. Parker, The teratogenic grid, [w:] J.P. Hallett, M.B. Skinner (eds), Roman Sexualities, Princeton 1997, s. 47-65.

${ }^{6}$ Cf. etiam komentarz do tego miejsca w recenzji A. Richlin, op. cit., s. 493.

${ }^{7}$ Zwracają na to uwagę również autorzy innych recenzji. Cf. H. Parker, op. cit.

${ }^{8}$ Cf. s. 189, ,[...] cunnilinctio, stosunkiem oralnym, w którym mężczyzna jest stroną aktywną”.

${ }^{9} \mathrm{Cf}$. H. Parker, op. cit., s. 51-58.
} 
zastąpić waginę". Adams źle rozumie ten epigram ${ }^{10}$, dodając, że język w tym utworze jest niespójny. W rzeczywistości Marcjalis zarzuca adresatowi utworu, że kradnie całusy młodzieńca i na dodatek go masturbuje. Epigram kończy konkluzja, że natura podzieliła mężczyznę na dwie części: jedną przeznaczyła dla kobiet, drugą dla mężczyzn. Poeta sugeruje, by adresat utworu korzystał ze swojego membrum virile w sposób należny w stosunku z chłopcem, czyli stosując pedicatio, zamiast przyjmować rolę stereotypowo kobiecą, używając swej ręki jako substytutu waginy (manus fututrix). Dlatego w tym wypadku przekład „oszczędź przynajmniej” wydaje się raczej nie pasować, skoro adresat zachęcany jest do sięgnięcia po więcej. Podobnych błędnych interpretacji w książce jest jeszcze sporo.

Kilka słów wypada również poświęcić czasownikowi pēdīcāre, któremu wciąż przypisuje się błędną etymologię (cf. s. 167) ${ }^{11}$. Trudno uznać ten czasownik za zapożyczenie z greki, a konkretnie za derywat od greckiego przymiotnika $\pi \alpha \imath \delta l \kappa o ́ s$. Pierwszym argumentem przeciw takiej interpretacji etymologicznej jest różnica iloczasu: $g r$. $\pi \alpha l \delta \breve{k}$ - vs. łac. pedīc-. Znakomita większość łacińskich czasowników na -icare stanowi derywaty odprzymiotnikowe i ma krótkie $i, \mathrm{np}$. publǐcus $\rightarrow$ publicare $^{12}$. Kolejnym argumentem jest ortografia: gdyby pedicare było zapożyczeniem z greki, musiałaby pojawić się w starożytności pisownia paedicare (cf. paedagogus), która według moich wstępnych badań nie ma poświadczenia w antyku. Wygląda więc na to, że pisownia ta została wprowadzona sztucznie do ortografii łacińskiej w średniowieczu lub nawet później wskutek tejże błędnej etymologii ${ }^{13}$. Dodatkowo uzus tego leksemu wskazuje wyraźnie, że nie jest on związany wyłącznie z pederastią - wykazywaniem erotycznego zainteresowania starszego erastesa młodszym eromenosem, ale ogólnie z penetracją anus (cf. Mart. XI 104; XI 99, Catull. XVI, gdzie ani Furiusz ani Aureliusz nie są przecież młodymi chłopcami). Cytowane w Seksualizmach fragmenty quod editis, nihil est: si vultis quod cacetis, copia est (z Nowiusza) na s. 189 oraz: qui verpam vissit, quid cenasse illum putes (CIL.IV.1884) na s. 187 mogą sugerować, że Rzymianie kojarzyli stosunek analny z defekacją ${ }^{14}$ (cf. etiam Priapea LXIX). Być może więc źródła czasownika pedicare trzeba dopatrywać się w pierwiastkach obecnych w pedere i podex.

Zupełnie osobno wypada omówić spolszczenia cytatów łacińskich: praca z pewnością zyskałaby na tym, gdyby tłumaczka przyjęła jakiś konsekwent-

${ }^{10} \mathrm{Na}$ co zwraca też uwagę w swojej recenzji A.D. Booth, op. cit., s. 363-364.

${ }^{11}$ Etymologii tego czasownika poświęcony zostanie oddzielny artykuł.

${ }^{12} \mathrm{~W}$ łacinie istnieją jedynie 2 inne czasowniki o podobnej budowie: aprīcor oraz nutrīco.

${ }^{13}$ Według F. Büchelera, Pedicare, RhM 13, 1858, s. 145, pisownię z dyftongiem ae wprowadził w XVII wieku holenderski uczony Gerhard Vossius, jego zdaniem, autor greckiej etymologii tego czasownika.

${ }^{14}$ Cf. C.A. Wiliams, Roman Homosexuality, Oxford 1999, s. 30; F.R.D. Goodyear, The Classical papers of A.E. Hausman, t. III, Cambridge 1972, s.1177 (reprint z 1915-1936). 
ny system przekładu konkretnych terminów na język polski, a przynajmniej terminologii związanej z fundamentalnymi założeniami rzymskiej koncepcji seksualności, skonstruowanymi na osi opozycji między byciem dominującym i zdominowanym oraz implikującymi formę współżycia leksemami: futuo, fello, irrumo, pedico. Czasowniki te thumaczone są często za pomocą tego samego wyrazu polskiego, np. s. 167: da pedicare „daj popieprzyć”, s. 180: pedicatur „pieprzę”, s. 163: qui futuere volet „kto chce popieprzyć”, s. 230: cum futuis, Polychrame, soles in fine cacare, / cum pedicaris, quid, Polychrame, facis? „gdy pieprzysz... a gdy ciebie pieprzą...”, s. 173: irrumo te „dopieprzę ci” lub w inny sposób nieimplikujący formy współżycia, np. s. 173: quia et irrumantur mulieres „ponieważ i na kobietach praktykują stosunki”; s. 52: $\lambda \alpha \iota \kappa a ́ \zeta \varepsilon ı v$ cupidae dicet avaritiae "powie chciwej żądzy: idź się puszczać" i tenże sam cytat na s. 181: „idź się gonić”; s. 32 qui pedicat „który uprawia seks z chłopcem".

Przekłady te stanowią więc pomoc w lekturze, ale nie mogą stać się materiałem interpretacyjnym dla czytelnika nie znającego łaciny. Pewnym problemem utrudniającym lekturę jest brak rozróżnienia czcionki tekstu łacińskiego od tekstu przekładu.

W wielu miejscach można dopatrywać się pewnych nieścisłości w polskim przekładzie, które wynikają z niewłaściwej interpretacji lub błędnego zrozumienia cytatu. Jako przykłady można podać następujące miejsca: s. 73: te futuet inguine „pieprzy słabiznę" raczej: „,wypieprzy cię [swoim] penisem”; s.181: cunnum lingere „lizać tyłek”, podczas gdy cunnus to określenie na żeńskie narządy rodne (scil. robić minete); s. 183: id est cum ego iaceo supinus et ipsa supra me crisat „to jest, gdy ja leżę na górze, a ona pode mną rozkosznie się porusza” raczej ,gdy ja leżę twarzą do góry [scil. na plecach], a ona nade mną rozkosznie się porusza" - jest to aluzja do equus eroticus; s. 72: exoletos suos [...] amputant „obcinają swoje tracące siły członki” raczej: „kastrują swoich kochanków wyrosłych z wieku młodzieńczego" - Seneka w cytowanym passusie opisuje pewne niewłaściwe zachowanie ludzi bogatych, którzy z zamiłowaniem oddają się rozpuście: tworzą haremy eunuchów, kastrując kochanków, którym z racji osiąganego wieku (exoleti) nie wypada już odgrywać roli biernego kochanka, w ten sposób hamują ich dojrzewanie, przedłużając tym samym ich chłopięctwo; s. 137, gdzie mowa o kobietach dotkniętych przypadłością utożsamianą z klitoromegalią (scil. przerostem łechtaczki): in venerem coactae veniunt „zmuszone są do uprawiania stosunków seksualnych" - kontekst rzeczywiście przysparza problemów, ale może raczej: „tylko przymuszone podejmują aktywność seksualną [scil. z mężczyzna]]" lub „zmuszone [tą przypadłością] penetrują waginy innych kobiet" - cf. użycie venus w znaczeniu cunnus: s. $138^{15}$. Czasami lekce-

\footnotetext{
${ }^{15}$ Cytowany w tym miejscu fragment z Marcjalisa przysparza wątpliwości, ale użycie słowa venus w tym kontekście może oznaczać „pożądanie” lub ogólnie „odbywanie stosunku”.
} 
ważone są formy gramatyczne: s. 77: invidia rumpantur ut ilia Cordo „Kordusowi wnętrzności z zazdrości pękały” raczej: ,aby pękł z zazdrości”; s. 32: Natalis verpe (CIL IV.1375) „fiuta Natalisa”, gdzie verpe nie jest raczej genetiwem od verpa, ale vocatiwem od verpus (tj. człowiek hojnie obdarzony przez naturę lub obrzezany), cytowany fragment inskrypcji należałoby więc traktować jako wyrażenie adresatywne, stąd też przekład powinien brzmieć „Natalisie, ty fiucie" ${ }^{16}$; s. 220: non facis mihi officium ,nie wypełnił wobec mnie obowiązku” raczej „,nie spełniasz”; s. 37: testes fumigato ... „okadzanie jądra” raczej „okadzaj jądra" (cf. inne przekłady imperativu futuri na s. 38); s. 42: tensionem autem fuisse veretri nimiam, ut cornu putaretur ,skurcz penisa był zaś tak silny, że członek był jak róg” raczej „erekcja była tak silna, że penis wydawał się twardy jak róg”; s. 47: illa solo fixos oculos aversa tenebat „on się odwrócił oczy trzymając wbite w ziemię” (przekład M. Brożka) raczej „ona odwróciwszy się trzymała oczy wbite w ziemię"; s. 52: statim fugiet sibi „,natychmiast się usunął" raczej „natychmiast się usunie”; s. 50: trupiter adfixo pudeat quem visere ramo „niech zawstydza szpetnie przyczepionym konarem tego, kto przyszedł popatrzeć” może raczej „którego aż wstyd oglądać z tak szpetnie przyczepionym konarem"; s. 41: virgiliores videbantur „wyglądają na bardziej męskich” raczej „wyglądali na hojniej obdarzonych przez naturę", virgiliores to derywat od virga nie vir; s. 45: cultoris vacat egra manu qui vimina nulla / falce metit... „pozbawiona wyczerpanej dłoni rolnika, która ni kłosów sierpem nie ścina...” raczej „,chora (scil. żona porównana do winnicy) pozbawiona jest ręki ogrodnika, który (ogrodniczym) nożem wcale gałązek nie przycina". Metrum wskazuje: aegră mănu - aegra jest przydawką do żony, nie ręki; s. 59: ...manu ventre pene bona patris laceraverat (Salustiusz o Katylinie) przytoczone w passusie o penisie i przetłumaczone jako: „dłonią, brzuchem roztrwonił niemalże ojcowiznę” raczej „przez rozrzutność (hazard), obżarstwo, rozpustę" ${ }^{17}$. Na s. 194: vis tu, inquit, magister, quotiens festinantem aliquem vides abligurire? „,czy chcesz, mistrzu, oblizać każdego, kogo dojrzysz, że się spieszy?” raczej „czy chcesz wylizać każdemu, kogo zobaczysz, że dochodzi?"

Warto także zwrócić uwagę na pojawiający się na s. 187 cytat: si vis esse satur nostrum potes esse Priapum / ipsa licet rodas inguina, purus eris. (Mart. XIV 70) z przekładem: ,jeśli chcesz się najeść, zostań naszym Priapem - choć słabizny pokosztujesz, brudu w ogóle nie poczujesz", co należałoby przetłumaczyć

\footnotetext{
${ }^{16}$ Sensem tej inwektywy może być komiczne odwołanie do wielkości członka, który stanowi większą część mężczyzny będącego adresatem inskrypcji, autor może sugerować, że fallus znajduje się w centrum zainteresowań i życiowych celów adresata (cf. CIL IV.4876). Całość inskrypcji CIL IV.1375, być może, nie jest napisana jedną ręką i, być może, nie należy łączyć jej w jedną całość.

${ }^{17}$ Ten sam błąd popełnił M. Kuryłowicz w książce Prawo i obyczaje w starożytnym Rzymie, Lublin 1994, s. 124: „ręką (rzucaniem kości) i żołądkiem (obżarstwem) bez mała majątek ojcowski roztrwonił".
} 
raczej jako ,jeśli chcesz się nasycić, możesz chapnąć naszego Priapa - godzi się, byś obgryzł - czysta sprawa” tudzież: „to znaczy: obgryź” (ipsa licet jako wyjaśnienie/rozwinięcie myśli z pierwszego wersu) lub rzeczywiście jako zdanie przyzwolone: ,jeśli chcesz się nasycić, możesz zjeść naszego Priapa, nawet gdybyś mu odgryzł przyrodzenie, to się nie splamisz/nie zbrukasz". Żart polega na dwuznaczności słowa satur = „syty strawą” i ,nasycony seksualnie”. Cytat umieszczony jest w passusie poświęconym jedzeniu, stąd też przekład zaproponowany przez tłumaczkę koliduje z zamysłem miejsca, w którym jest przytaczany. Dodatkowo tytuł cytowanego apophoreton: Priapus siligineus, tj. „figurka Priapa ulepiona z ciasta" ${ }^{18}$, sugeruje, że Priap mógł być ciastkiem otrzymanym przez jakiegoś gościa w trakcie uczty jako deser lub jako upominek podczas święta Saturnaliów. W epigramie bożek zachęca, by głodny adresat odgryzł mu przyrodzenie, a nic złego się nie stanie. Purus eris można rozumieć tutaj jako „nadal pozostaniesz czysty obrzędowo” (= nie robisz niczego złego, bo w ten sposób uczcisz Priapa) lub ,nie obawiaj się - jesteś głodny, to cię usprawiedliwia”, albo „nie doznasz pedicatio, czyli zniesiesz mniejsze zło"19 lub „to tylko ciastko, nie prawdziwy posążek, więc to cię nie splami”. Kolejnym cytatem związanym z jedzeniem jest: quod editis, nihil est: si vultis quod cacetis, copia est na s. 189 ,nie ma nic, co byście zjedli: jeśli chcecie tego, coście wysrali, to jest tego do woli” sens raczej, „nie macie, co jeść, ale jak chcecie co wysrać, to strasznie tego dużo"20.

Czasami zdarza się, że jakiś cytat pojawia się w książce kilkakrotnie i za każdym razem jest przekładany zgoła inaczej, np. s. 32: CIL.IV.1884 qui verpam vissit, quid cenasse illum putes ,jak sądzisz, co zje na kolację ten, który widział kutasa?”, natomiast s. 187: „ten, kto odwiedził kutasa, jak sądzisz, co zjadł na kolację?". Nie ulega wątpliwości, że w przekładzie powinien pojawić się czas przeszły: „co zjadł”, można mieć natomiast wątpliwości co do czasownika vissit, czy jest to frequentativum od videre czy też oznacza tacite pedere (cf. s. 330), co mogłoby być aluzją do pedicatio (cf. s. 186, Mart. II 51, XII 75 oraz Priapea LXIX) ${ }^{21}$. Kolejne trzy przykłady: s. 93: et laeva lacrimas muttoni absterget amica ,a przyjaciółka z lewej strony ociera łzy Wackowi” vs. bliższy oryginałowi przekład ze s. 52: „tymczasem lewą ręką przyjaciółka ociera łzy penisowi”; s. 158: futuebatur Romanorum cunnus adtractis pedibus „dymają cipkę rzymskich obywateli o złączonych stópkach” vs. s. 165: „dymali tyłki rzymskich obywateli o ściśniętych stópkach” sens raczej: „zadarłszy nogi

\footnotetext{
${ }^{18}$ A dokładniej: z mąki pszennej.

${ }^{19}$ Podobne użycie zaimka noster znajduje się w: Mart. XI 19. Z kolei w sprawie zabawy terminem purus vs. impurus w odniesieniu do jedzenia cf. Mart. IX 63.

${ }^{20}$ C.A. Wiliams, op. cit., s. 30, sugeruje, że to aluzja do pedicatio; co do formy editis jako archaicznego optativu cf. F. Neue, Formenlehre der lateinischen Sprache, t. III, Hildesheim 1985, s. 310 (reprint trzeciego wydania z 1897 r.).

${ }^{21}$ Cf. także C.A. Wiliams, op. cit., s. 30.
} 
Rzymianom dymali ich cipki" - pes jako pars pro toto, adtractis pedibus to abl. abs. cf. Catull. XV 18. Dalej: CIL.IV.1825 pojawia się w książce kilkakrotnie i za każdym razem z innym przekładem, np. s. 223: Cosmus equitaes magnus cinaedus et fellator: esuris apertis maribus „Kosmus jeździec wielki rozpustnik i obciągacz: głodnyś wśród odkrytych samców” i na s. 187: „Kosmus ekwita, wielki rozpustnik i spec od laski, sporo byś pochłonął”. Odczytanie tej inskrypcji budzi wiele wątpliwości ${ }^{22}$, lecz przyjąwszy lekcję z equitaes (trudno poprzeć jedną z wielu proponowanych możliwości odczytania drugiej części inskrypcji), należałoby rozumieć: „Kosmusie, pojeździłbyś sobie” lub jak sugerują inni equitia es ,jesteś jak stajnia” - wyraźna aluzja do equus eroticus.

Inną dyskusyjną inskrypcją cytowaną przez Adamsa (s. 173) jest CIL IV.10197 przytaczana w takiej oto lekcji: elige, [p]uela. iruman[ti] [...] nuli negant. Przełożone jest to w sposób następujący: „weź do buzi, dziewko. Żadnemu, co wkłada, [...] nie odmawiają". W komentarzu znajduje się notka, że wydawca uzupełnił lukę słowami manu polluenti, której to koniektury Adams nie może się dopatrzyć na załączonej ilustracji. Nie ulega jednak wątpliwości, że w tym miejscu coś jest napisane, stąd też łączenie irrumanti nulli negant przy celowym pomijaniu fragmentu pomiędzy tymi elementami wydaje się nieuzasadnione. Można by zaproponować zupełnie inną lekcję dającą zgoła inny sens: elige puellam irrumandam, manu pollent/polient, nulli negant, tj. „,wybierz dziewczynę, która ci obrobi - mają zdolne ręce (wypolerują ręką), nikomu nie odmawiają". Byłby to rodzaj reklamy domu publicznego, nie zaś napis skierowany do nie wiadomo jakiej dziewczyny, nakłaniający ją do spółkowania nie wiadomo z kim.

W niektórych wypadkach można wskazać pewne błędy stylistyczne czy logiczne, np. s. 304: elevans Priapo $<n>$ frequenti fricatura porrixabam ,przez ten masaż mego Priapa usztywniałem”, gdzie czytelnik odnosi wrażenie, że to podmiot zdania zesztywniał przez masaż penisa, a nie że przez ów masaż wywoływał u siebie erekcję; s. 187: Catull. XXVIII: nam nihilo minore verpa farti estis „nie mniejszym kutasem żeście się napchali” może raczej: „nie mniejszym kutasem jesteście napchani/nafaszerowani”. W języku łacińskim, zwłaszcza w sferze seksu, zastosowanie odpowiedniej strony gramatycznej czasownika odgrywa bardzo ważną rolę, ponieważ odzwierciedla ono rzymską koncepcję dominacji i bycia zdominowanym, stąd też nierozważne użycie kategorii strony w przekładzie może budzić kontrowersje, np: s. 173: Mart. IV 50: nemo est, Thai, senex ad irrumandum ,nikt nie jest, Taido, za stary, by mu obciągnaćc”, podczas gdy sens jest taki, że starość nie niesie takiej impotencji, by nie zdołać komuś włożyć do ust - nikt nie jest za stary, by móc wciąż być mężczyzną.

Mimo wspomnianych mankamentów opracowania oraz błędów pojawiających się w przekładzie cytatów łacińskich wyrazić należy uznanie dla wydawców

\footnotetext{
${ }^{22}$ Cf. A. Varone, Erotica Pompeiana, Roma 2001, s. 140.
} 
i thumaczki za podjęcie tematu często unikanego przez badaczy literatury antycznej i języka starożytnych Rzymian. Warto zauważyć, że książka ta, mimo swoich wad, jest nadal jedyną monografią poświęconą łacińskiemu słownictwu erotycznemu. Pozostaje więc żywić nadzieję, że w kolejnym wydaniu Seksualizmów łacińskich wydawcy dokonają koniecznych poprawek, a sama książka spowoduje w Polsce ożywioną dyskusję na temat łacińskiej leksyki erotycznej.

\section{OBSERVATIONES QUAEDAM IN POLONAM EDITIONEM VOCABULARII EROTICI LINGUAE LATINAE A I.N. ADAMS CONSCRIPTI}

\section{Sum marium}

Hoc superiore anno in lucem prodiit Polona editio libri The Latin Sexual Vocabulary a I.N. Adams conscripti, quem Polonice reddendum curavit Ioanna Janik. Opus illud, quamvis valde desideratum et propter thema susceptum vera laude dignum, haud exiguo lapsuum numero, qui in Polona interpretatione exemplorum Latinorum occurrunt, admirationem affert singularem. Poloni editores tacito quoque praetermisisse videntur libri censuras, quae primam eius editionem Anglicam sequerentur, ubi iuste quidem operis vitia enumerarentur. Nihil ergo correctum, nihil ex enumeratis vitiis in illa recentissima editione adnotatum est (praeter corrigendorum et adnotandorum indicem in ultimis pagellis versionis propriae positum). Nonnullis ergo mirum fortasse appareat librum quendam vitiosum ad scientiarum disciplinas investigandas spectantem nunc triginta dilapsis annis ab eius prima editione in vernaculas linguas interpretari, cum certe illius temporis spatio scientiarum status multo progressus sit. Nullum tamen opus aliud vocabulis Venereis Romanorum adhuc dicatum est, quam ob rem duo restant faciunda: aut liber diligentissime recensendus, aut materies ipsa denuo investiganda et novo libro tractanda. Quod nisi fiat, sperandum est proximam libri editionem correctiorem fore, hac praesenti autem philologorum animos ad oriundam disputationem de Latinis vocabulis eroticis admoveri. 